\title{
The Mediating Effects of Customer and Competitor Orientations on New Product Success
}

\author{
Wong, Kam Sing (Corresponding author) \\ Faculty of Management and Administration, Macau University of Science and Technology \\ Avenida Wai Long, Taipa, Macao, China \\ E-mail: kswong@must.edu.mo \\ Canon Tong \\ International Graduate School of Business, University of South Australia \\ Adelaide SA, Australia \\ E-mail: canon.tong@unisa.edu.au
}

Received: February 12, 2011 Accepted: March 10,2011 doi:10.5539/ijbm.v6n8p34

\begin{abstract}
Market orientation, innovation, and new product success are receiving increasing attention from practitioners and scholars. Although producing new products is critical to the profitability of a firm and its long-term survival, it is a costly and risky business because of low success rates. The research on which this paper is based investigated key determinants of new product success from the perspective of team members responsible for developing new products. Findings from 217 respondents support the hypotheses that new product success is driven by cooperation between research and development and marketing. It was also found that customer and competitor orientations have a mediating effect on the association between research and development and marketing cooperation and new product success. The study contributes to the body of knowledge relating to new product success, marketing, and management. The findings provide information for managers involved in the development and marketing of new products, to help ensure their success. This will benefit both their organizations and the community at large.
\end{abstract}

Keywords: Customer orientation, Competitor orientation, Research and development, Marketing, New product success

\section{Introduction}

Issues relating to new product success (NPS) have attracted the attention of researchers for many years (Song \& Parry, 1997; Calantone, Schmidt, \& Song, 1996; Denison, Hart, \& Kahn, 1996; Dougherty, 1992; Kazanjian, 1988). NPS is critical to the profitability and long-term survival of many firms (Sivadas \& Dwyer, 2000; Calantone et al., 1996; Zirger \& Maidique, 1990). However, developing a new product is a costly and risky business with an average failure rate of about $30 \%$ to $75 \%$ depending on the industry and level of innovation concerned (Stevens \& Burley, 2003; Sivadas \& Dwyer, 2000; Boulding, Morgan, \& Staelin, 1997).

Teamwork and cross-functional cooperation, especially cooperation between research and development and marketing (R\&D-marketing cooperation), is a critical factor affecting new product success (Shaw, Shaw, \& Enke, 2004; Olson, Walker, Ruekert, \& Bonner, 2001; Atuahene-Gima \& Evangelista, 2000; Song, Neeley, \& Zhao, 1996). Cross-functional cooperation also forms one of the three key elements of market orientation (Augusto \& Coelho, 2009; Balakrishnan, 1996; Narver \& Slater, 1990).

Most studies relating to NPS have been carried out in Western countries (Nakata, Im, Park, \& Ha, 2006), so the purpose of this research was to gain a better understanding of NPS in China. This was achieved by using a research framework for examining the effects of R\&D-marketing cooperation on NPS in China's electronics industry.

\section{Literature Review}

\subsection{New product success}

The measurement of NPS can be broadly classified into absolute measures, such as profitability, sales revenues and overall success; relative measures, such as original target and competitor success; and purely subjective judgement. The majority of scholars used measures relative to the known performance of competitors (Paladino, 2007; Baker \& Sinkula, 2005; Narver, Slater, \& MacLachlan, 2004).

Profitability is the most widely accepted way of measuring NPS (Paladino, 2007; Calantone, Chan, \& Cui, 2006; 
Song, Dyer, \& Thieme, 2006; Atuahene-Gima, Slater, \& Olson, 2005; \& Pelham, 1999); sales revenue is the second most common measure (Paladino, 2007; Atuahene-Gima et al., 2005; Matsuno, Mentzer, \& Ozsomer, 2002); while success rate is another common measure (Paladino, 2007; Baker \& Sinkula, 2005; Song, Xie, \& Dyer, 2000).

\subsection{R\&D-marketing cooperation}

Teamwork is important to NPS as it enables members from various departments to bring their knowledge and expertise together for the purposes of better satisfying customer needs at lower costs and better quality, with greater efficiency (Sethi, Smith, \& Park, 2001).

Among the various teamwork and cross-functional cooperative relationships, the one between R\&D and marketing is considered as one of the most important and challenging to manage (Rodríguez, Pérez, \& Gutiérrez, 2007; Rodríguez, Pérez, \& Gutiérrez, 2007a; Becker \& Lillemark, 2006; Sherman, Berkowitz, \& Souder, 2005; Shaw et al., 2004; Atuahene-Gima \& Evangelista, 2000; Song et al., 1996). Empirical studies have found that, despite a complex and often problematic relationship, successful R\&D-marketing collaboration can help a firm better understand customer needs and preferences (Griffin \& Hauser, 1996); reduce new product development (NPD) uncertainties (Becker \& Lillemark, 2006; Song et al., 1996); improve the performance of a new product in terms of quality, cost and time-to-market (Shaw et al., 2004; Song \& Parry, 1997; Swink \& Song, 2007); and improve the success rate of new products (Massey \& Kyriazis, 2007).

\subsection{Customer orientation}

Global competition increases market turbulence as well as the richness and diversity of knowledge possessed by customers and competitors (Achrol, 1991). A customer-oriented firm which commits itself to superior customer service and integrates customer preferences and needs into its product development strategy has the best guarantee for long-term success (Gatignon \& Xuereb, 1997; Deshpandé \& Webster, 1989). To survive in a highly competitive marketplace, a firm's priorities should be to: identify the right market; formulate the most suitable entry strategy; target customers that can provide high life-time value; fully understand customers' preferences and needs; and closely monitor changing market needs so that new products can be developed to satisfy them (Ching, Ng, Wong, \& Altman, 2004; Tse, Sin, Yau, Lee, \& Chow, 2004; Achrol \& Kotler, 1999; Rust, Inman, Jia, \& Zahorik, 1999; Bowman \& Gatignon, 1996). However, a competitive new product should not only be customer-oriented but also a forward-looking product that anticipates and meets potential gaps in the market (Hurley \& Hult, 1998; Kohli \& Jaworski, 1990). In other words, when a product is still on the drawing board, the firm should have already grasped what makes the target customers unhappy about the existing products, and develop new products to close the gap ahead of its competitors (Mattson, 1985). To this end, a firm should timely and accurately generate customer demand information and pass it to the R\&D and marketing departments so that they can work together to effectively meet market needs (Voss \& Voss, 2000; Kohli \& Jaworski, 1990; Mattson, 1985).

A firm's ability to cheaply and swiftly introduce new products that meet customer needs is the key to long-term success (Datar, Jordan, Kekre, Rajiv, \& Srinivasan, 1997). Customer orientation means that the attention of the R\&D and marketing departments are attuned to the voices of its customers (Atuahene-Gima \& Evangelista, 2000; Griffin \& Hauser, 1993). Incorporating this as a part of the firms organizational culture, increases the chances of NPS (Griffin \& Hauser, 1993).

\subsection{Competitor orientation}

Competitor orientation can enhance a firm's competitive advantage by allowing it to benchmark with, learn from, imitate, and improve on the products of successful competitors (Drew, 1997; Day \& Wensley, 1988). Unlike the long-term benefits of customer orientation, empirical research has produced widely divergent findings on the relationship between competitor orientation and organisational performance: Narver and Slater (1990) and Noble, Sinha, and Kumar (2002) identified a positive relationship between competitor orientation and organisational performance; Harrison-Walker (2001) discovered that no such relationship exists; Armstrong and Green (2007) and Armstrong and Collopy (1996) found the existence of a negative relationship; and Luo, Rindfleisch, and Tse (2007) claimed that there is a curvilinear relationship between the two. Armstrong and Collopy (1996) argued that competitor orientation reduces the profitability of a firm and suggested that firms should focus on maximising their own profit and ignore their competitors' tactics completely.

Caution, however, should be taken in interpreting these findings, as no common definition has yet been given to the term 'competitor orientation.' For example, Armstrong and Collopy (1996) found General Electric (GE) to be one of the least competitor oriented firms among the American industrial firms that they studied, a classification which ran contrary to GE's own claim that "We will be number one or two in every market where we compete" (Fulmer, 1997, p.65). One possible reason for this anomaly is that the superior performance of GE was not the result of its lack of competitor orientation (Armstrong \& Collopy, 1996), but rather it was an early embrace of competitor orientation that allowed the company to become the leader in almost all segments of competition in the first place (Fulmer, 1997; Wilson, 1992). 


\section{Model Development}

\subsection{Theoretical model}

A research framework was developed for this study to show the direct and indirect influences of R\&D-marketing cooperation on NPS. Figure 1 below shows the proposed research model with four variables; R\&D-marketing cooperation, customer orientation, competitor orientation, and NPS.

\section{[INSERT FIGURE 1 HERE]}

\subsection{Research hypotheses}

In China's highly competitive electronics industry, the best way to develop new products is to have R\&D and marketing departments working together so that the knowledge and experience possessed by one department can complement the other; the two parties can use their combined strength to contribute to the success of a new product. Therefore, the first hypothesis was:

H1: R\&D-marketing cooperation positively affects NPS.

Having R\&D and marketing departments working together enables a company to better understand its customers and competitors. Hence, the second and third hypotheses were:

H2: R\&D-marketing cooperation positively affects customer orientation.

H3: R\&D-marketing cooperation positively affects competitor orientation.

With better knowledge of its customers, a company can develop products that best meet its customer needs. The fourth hypothesis therefore was:

H4: Customer orientation positively affects NPS.

With better knowledge of its competitors, a company has a higher chance to develop products that outperform those of its competitors. Therefore, the fifth hypothesis was:

H5: Competitor orientation is positively related to NPS.

$\mathrm{R} \& \mathrm{D}$ and marketing cooperation can enhance customer orientation in a NPD team, which in turn can increase the success rate of new products. Therefore, the sixth hypothesis was:

H 6: Customer orientation mediates the relationship between R\&D-marketing cooperation and NPS.

R\&D and marketing cooperation can enhance competitor orientation of a NPD project team which, in turn, can increase the success rate of new products. Therefore, our seventh hypothesis was:

H 7: Competitor orientation positively mediates the relationship between R\&D-marketing cooperation and NPS.

\subsection{Measures}

In order to fully capture the essential features and multidimensional aspects of the four variables, every single variable was measured by the use of multi-item scales (Hoegl \& Gemuenden, 2001; Song \& Montoya-Weiss, 2001; Sivadas \& Dwyer, 2000; Olson, Walker, \& Ruekert, 1995).

To capture the essence of R\&D-marketing cooperation as the model's only independent variable, items used by Rodriguez, et al. (2008) were adopted. However, instead of the seven-point Likert scale used in Rodriguez et al's study, a five-point Likert scale was used comprising 'Strongly Disagree', 'Disagree', 'Neutral', 'Agree', and 'Strongly Agree'.

NPS is the model's dependent variable. The concept of NPS has been discussed and measured by many researchers, including Deshpande, Farley, and Webster (1993), and Song, Xie, and Dyer (2000). The measure of NPD success adopted by this research was the performance of new products in relation to that of its major competitors, using Paladino's (2007) three measures: 'success rate', 'revenue', and 'profitability'.

Customer orientation was hypothesized as having a moderating effect on the relationship between the independent variable (R\&D-Marketing cooperation) and the dependent variable (NPS). The essence of customer orientation is the creation of a customer-oriented culture aimed at bringing exceptional value to customers by continuously understanding and satisfying their needs (Ching et al., 2004; Tse et al., 2004; Achrol \& Kotler, 1999; Rust et al., 1999; Bowman \& Gatignon, 1996). For this research, the five items used by Kahn (2001) was adopted to measure customer orientation against a five-point Likert scale of 'Strongly Agree', 'Agree', 'Neutral',' 'Disagree', and 'Strongly Disagree'.

\subsection{Data collection}

An online questionnaire was used for data collection because of its relatively low cost, fast response, convenience of administration, ease of data entry and analysis, and absence of geographical restrictions (Evans \& Mathur, 2005; Bhattacherjee, 2001). In addition to these benefits, it has been also suggested that the anonymity of online questionnaires makes participants more willing to give true answers to the questions (Barak \& Gluck-Ofri, 2007; Suler, 2004; Nambisan, 2002; Joinson, 2001).

As invitations were sent via email and the survey was conducted online, the response rate was expected to be in 
the range of $4.4 \%$ to $12.3 \%$ (Bae \& Kang, 2008; Ranchhod \& Zhou, 2001). In the event, since 217 responses were received from the 2,548 email invitations delivered, a response rate of $8.5 \%$ was achieved.

\subsection{Analysis procedure}

Prior to analysing the data collected from the online survey, a reliability test was conducted along with exploratory factor analysis (EFA) and Cronbach's alpha coefficient. Correlations analysis was used to test the relationships among all variables in the research as well as hypotheses H1 to H5. Linear regression, using the method proposed by Baron and Kenny (1986), was conducted to test hypotheses H6 and H7 relating to the mediating effects of customer orientation and competitor orientation on the relationship between R\&D-marketing cooperation and NPS.

\section{Results and Findings}

\subsection{Exploratory factor analysis and reliability analysis}

All measuring scales were adapted from prior studies published in peer reviewed journals, but in order to fit the specific needs of this study, some modification of the questions were made. To ensure that such changes would not affect the quality of the study, exploratory factor analysis (EFA) with varimax rotation was performed to extract factors with eigenvalues greater than 1, using IBM SPSS statistics for Windows version 19. The purpose of using factor analysis is to discover the underlying variables, the hidden factors that cannot be measured directly, using a larger set of measurable items (Reagans \& McEvily, 2003; Batra, Homer, \& Kahle, 2001). The data yielded a Kaiser-Meyer-Olkin (KMO) measure of sampling adequacy test result of 0.921, which was well above the acceptable limit of 0.8 (Kaiser \& Rice, 1974). Bartlett's test of sphericity yielded an approximate Chi-Square value of 2151.685 with 153 degree of freedom $(\mathrm{p}<0.000)$, indicating that the data were suitable for factor analysis.

As shown in Table 1, EFA yielded four latent variables from the data which explained $67.8 \%$ of the total variance. The four variables extracted were R\&D-marketing cooperation, customer orientation, competitor orientation, and NPS.

\section{[INSERT TABLE 1 HERE]}

Subsequent to EFA, Cronbach's alphas tests were conducted to test the internal consistence of the extracted latent variables (Coakes, Steed, \& Price, 2008). As shown in Table 2, all Crobbach's alpha coefficients were found to be greater than 0.8 (Shin, Collier, \& Wilson, 2000), indicating that all variables had high internal consistence among their respective measuring items.

\section{[INSERT TABLE 2 HERE]}

\subsection{Hypotheses testing}

Results from the KMO test, Bartlett's test and the Cronbach's alpha coefficients indicated that the measuring scales and data were reliable and suitable for further tests.

Correlations among R\&D-marketing cooperation, customer orientation, competitor orientation, and NPS were computed by using SPSS. Table 3 shows the correlation coefficients. The variable of R\&D-marketing cooperation was found significantly $(\mathrm{p}<0.01)$ correlated with NPS $(\mathrm{R}=0.595)$, customer orientation $(\mathrm{R}=0.568)$ and competitor orientation $(\mathrm{R}=0.306)$, therefore, giving support to $\mathrm{H} 1, \mathrm{H} 2$ and $\mathrm{H} 3$. Meanwhile, both customer orientation and competitor orientation were found significantly $(\mathrm{p}<0.01)$ correlated with NPS $(\mathrm{R}=0.585$ and 0.291 respectively), giving support to $\mathrm{H} 4$ but rejecting $\mathrm{H} 5$.

\section{[INSERT TABLE 3 HERE]}

After examining the relationships among the four variables, linear regression was used to test the mediating effects of customer orientation and competitor orientation on the relationship between R\&D-marketing cooperation and NPS. As shown in equation 1 of Table 4, the independent variable of R\&D-marketing cooperation significantly influenced the dependent variable of NPS $(\mathrm{R}=0.595, \mathrm{p}<0.001)$. In equation 2 , $R \& D$-marketing cooperation significantly influenced the mediator of customer orientation $(R=0.568, p<0.001)$. In equation 3 , the mediator of customer orientation significantly influenced NPS $(R=0.585, p<0.001)$. By adding the mediator of customer orientation, the influence of R\&D-marketing cooperation on NPS significantly $(\mathrm{p}<0.001)$ reduced from 0.595 in equation 1 to 0.388 in equation 4 . Therefore, all conditions in Baron and Kenny (1986) were fulfilled and, therefore, giving support to H6.

\section{[INSERT TABLE 4 HERE]}

As shown in equation 1 of Table 5, the independent variable of R\&D-marketing cooperation significantly influenced the dependent variable of NPS $(\mathrm{R}=0.595, \mathrm{p}<0.001)$. In equation 2 , R\&D-marketing cooperation significantly influenced the mediator of competitor orientation $(\mathrm{R}=0.306, \mathrm{p}<0.001)$. In equation 3 , the mediator of competitor orientation significantly influenced NPS $(\mathrm{R}=0.291, \mathrm{p}<0.001)$. By adding the mediator of competitor orientation, the influence of R\&D-marketing cooperation on NPS slightly but significantly $(\mathrm{p}<0.05)$ reduced from 0.595 in equation 1 to 0.558 in equation 4. Therefore, all conditions in Baron and Kenny (1986) were fulfilled thereby giving support to $\mathrm{H} 7$. 


\section{[INSERT TABLE 5 HERE]}

\section{Discussion}

In today's highly competitive global market, a firm's ability to maintain its competitive edge depends very much on whether it can develop and commercialise new products quickly in response to or in anticipation of market needs. The key to achieving this is cooperation among the teams responsible for developing and marketing new products (Denison et al., 1996; Keller, 2001; Olson et al., 2001; Sethi et al., 2001; Atuahene-Gima \& Evangelista, 2000). Being customer-oriented allows the teams to develop new products that meet and exceed the needs of their customers, while being competitor-oriented enables the teams to develop new products quicker and better than their competitors.

Market orientation has been generally considered as a single concept (Hult \& Ketchen, 2001; Cooper \& Kleinschmidt, 1993). However, the varying levels of influence that R\&D-marketing cooperation, customer orientation and competitor orientation have on NPS, as revealed by this research, indicate that market orientation should be studied and understood from three separate perspectives: R\&D-marketing cooperation, customer orientation, and competitor orientation.

This research found that R\&D-marketing cooperation is a key factor for NPS in that it encourages the sharing of ideas and the making of joint decisions so that tasks can be accomplished in the most effective way. The significantly positive influence of R\&D-marketing cooperation on NPS suggests that firms should make a deliberate effort to foster cooperation between $\mathrm{R} \& \mathrm{D}$ and marketing because a power struggle between the two inhibits the effectiveness of their efforts.

Customer orientation was found by this study to have a significantly positive influence on NPS. A firm that strives to best serve its customers is one which is not only capable of developing products that meet their needs but also products that they aspire to. Such products will have a higher rate of success at its launch and sustain the success longer thereafter. A product development team with a customer-oriented mindset can improve the overall performance of a firm by identifying profitable market segments and by creating new products that serve those segments better than competitors. This in turn allows firms to capture markets quickly and economically.

Competitor orientation is a double-edged sword. While a highly competitor-oriented team can respond to competition quickly by developing better products to capture market share, the mediating effect of competitor orientation on NPS is not as significant as the mediating effect of customer orientation. It is therefore possible that a company which is too competitor-oriented may simply follow the products of its competitors and eventually force market participants to compete with one another in a cut-throat price war.

\section{Limitation and Suggestion for Future Research}

While this research aimed at providing a better understanding of the antecedents of NPS, it has some limitations. The research was conducted in the context of China's electronics industry, which may have led to some cultural-specific and industry-specific characteristics being incorporated in the research findings. The model used in this research should be empirically tested in other countries and industries in order to enhance its generalisability.

The cross-sectional nature of this study imposed a second limitation. As with other cross-sectional studies, this study could only capture and analyze a snapshot of a phenomenon (Sriram \& Stump, 2004) and, therefore, failed to examine the change of participants' perception over time. This can be overcome by conducting a longitudinal study to track the perception of those involved in new product development over a considerable period of time. (Bryman, 2008).

The research was also limited by the use of a self-report questionnaire, which made it impossible to validate respondents' profile or to clarify the meaning of questions (Bryman, 2008). To bolster confidence in the validity of respondent profiles as well as adding to the rigor of future studies, the use of both online and hardcopy questionnaires is recommended as a form of triangulation.

\section{Conclusion}

This study of the impact of R\&D and marketing cooperation, customer orientation and competitor orientation on new product success has significant theoretical and managerial implications. Using customer orientation and competitor orientation as two separate mediators in the research framework instead of grouping them together with inter-functional cooperation as a single concept, as previous studies did, has shed light on alternative ways to study market orientation. The affirmation of the importance of R\&D and marketing cooperation, customer orientation and competitor orientation to the success of new products should encourage firms to direct their resources to activities such as team building and to adopt customer-oriented and/or competitor-oriented behaviour.

\section{References}

Achrol, R. S. (1991). Evolution of the Marketing Organization: New Forms for Turbulent Environments. Journal of Marketing, 55(4), 77-93. 
Achrol, R. S., \& Kotler, P. (1999). Marketing in the Network Economy. Journal of Marketing, 63(Special Issue), 146-163.

Armstrong, J. S., \& Collopy, F. (1996). Competitor Orientation: Effects of Objectives and Information on Managerial Decisions and Profitability. Journal of Marketing Research, 33(2), 188-199.

Armstrong, J. S., \& Green, K. C. (2007). Competitor-oriented Objectives: The Myth of Market Share. International Journal of Business, 12(1), 116-134.

Atuahene-Gima, K., \& Evangelista, F. (2000). Cross-Functional Influence in New Product Development: An Exploratory Study of Marketing and R\&D Perspectives. Management Science, 46(10), 1269-1284.

Atuahene-Gima, K., Slater, S. F., \& Olson, E. M. (2005). The Contingent Value of Responsive and Proactive Market Orientations for New Product Program Performance. Journal of Product Innovation Management, 22(6), 464-482.

Augusto, C., \& Coelho, F. (2009). Market orientation and new-to-the-world products: Exploring the moderating effects of innovativeness, competitive strength, and environmental forces. Industrial Marketing Management, 38(1), 94-108.

Bae, H. S., \& Kang, S. (2008). The Influence of Viewing an Entertainment-Education Program on Cornea Donation Intention: A Test of the Theory of Planned Behavior. Health Communication, 23(1), 87 - 95.

Baker, W., \& Sinkula, J. (2005). Environmental marketing strategy and firm performance: Effects on new product performance and market share. Journal of the Academy of Marketing Science, 33(4), 461-475.

Balakrishnan, S. (1996). Benefits of customer and competitive orientations in industrial markets. Industrial Marketing Management, 25(4), 257-269.

Barak, A., \& Gluck-Ofri, O. (2007). Degree and Reciprocity of Self-Disclosure in Online Forums. Cyber Psychology and Behavior, 10(3), 407-417.

Baron, R. M., \& Kenny, D. A. (1986). The Moderator-Mediator Variable Distinction in Social Psychological Research: Conceptual, Strategic, and Statistical Considerations. Journal of Personality and Social Psychology, 51(6), 1173-1182.

Batra, R., Homer, P. M., \& Kahle, L. R. (2001). Values, Susceptibility to Normative Influence, and Attribute Importance Weights: A Nomological Analysis. Journal of Consumer Psychology, 11(2), 115-128.

Becker, M. C., \& Lillemark, M. (2006). Marketing/R\&D integration in the pharmaceutical industry. Research Policy, 35(1), 105-120.

Bhattacherjee, A. (2001). Understanding information systems continuance: an expectation-confirmation model. MIS Quarterly, 25(3), 351-370.

Boulding, W., Morgan, R., \& Staelin, R. (1997). Pulling the Plug to Stop the New Product Drain. Journal of Marketing Research, 34, 164-176.

Bowman, D., \& Gatignon, H. (1996). Order of Entry as a Moderator of the Effect of the Marketing Mix on Market Share. Marketing Science, 15(3), 222-242.

Bryman, A. (2008). Social Research Methods (3rd ed.). New York: Oxford University Press.

Calantone, R. J., Chan, K., \& Cui, A. S. (2006). Decomposing Product Innovativeness and Its Effects on New Product Success. Journal of Product Innovation Management, 23(5), 408-421.

Calantone, R. J., Schmidt, J. B., \& Song, X. M. (1996). Controllable Factors of New Product Success: A Cross-National Comparison. Marketing Science, 15(4), 341-358.

Ching, W. K., Ng, M. K., Wong, K. K., \& Altman, E. (2004). Customer Lifetime Value: Stochastic Optimization Approach. The Journal of the Operational Research Society, 55(8), 860-868.

Coakes, S. J., Steed, L., \& Price, J. (2008). SPSS Version 15.0 for Windows: Analysis without Anguish. Milton, Queensland: John Wiley \& Sons Australia, Ltd.

Cohen, M. A., Eliashberg, J., \& Ho, T. H. (1996). New Product Development: The Performance and Time-to-Market Tradeoff. Management Science, 42(2), 173-186.

Cooper, R. G., \& Kleinschmidt, E. J. (1993). Screening new products for potential winners. Long Range Planning, 26(6), 74-81.

Datar, S., Jordan, C., Kekre, S., Rajiv, S., \& Srinivasan, K. (1997). New Product Development Structures and Time-to-Market. Management Science, 43(4), 452-464.

Day, G. S., \& Wensley, R. (1988). Assessing Advantage: A Framework for Diagnosing Competitive Superiority. The Journal of Marketing, 52(2), 1-20.

Denison, D. R., Hart, S. L., \& Kahn, J. A. (1996). From Chimneys to Cross-Functional Teams: Developing and Validating a Diagnostic Model. The Academy of Management Journal, 39(4), 1005-1023. 
Deshpandé, R., \& Webster, F. E. (1989). Organizational Culture and Marketing: Defining the Research Agenda. Journal of Marketing, 53(1), 3-15.

Deshpandé, R., Farley, J. U., \& Webster, F. E. (1993). Corporate Culture, Customer Orientation, and Innovativeness in Japanese Firms: A Quadrad Analysis. Journal of Marketing, 57(1), 23-37.

Dougherty, D. (1992). Interpretive Barriers to Successful Product Innovation in Large Firms. Organization Science, 3(2), 179-202.

Drew, S. A. W. (1997). From knowledge to action: the impact of benchmarking on organizational performance. Long Range Planning, 30(3), 427-441.

Evans, J. R., \& Mathur, A. (2005). The value of online surveys. Internet Research, 15(2), 195-219.

Fulmer, R. M. (1997). The evolving paradigm of leadership development. Organizational Dynamics, 25(4), 59-72.

Gatignon, H., \& Xuereb, J.M. (1997). Strategic Orientation of the Firm and New Product Performance. Journal of Marketing Research, 34(1), 77-90.

Griffin, A., \& Hauser, J. R. (1993). The Voice of the Customer. Marketing Science, 12(1), 1-27.

Griffin, A., \& Hauser, J. R. (1996). Integrating R\&D and marketing: A review and analysis of the literature. Journal of Product Innovation Management, 13(3), 191-215.

Harrison-Walker, L. J. (2001). The measurement of a market orientation and its impact on business performance. Journal of Quality Management, 6(2), 139-172.

Hickson, D. J., \& Pugh, D. S. (2001). Management Worldwide: Distinctive Styles Amid Globalization (2nd. ed.), London: Penguin Group.

Hoegl, M., \& Gemuenden, H. G. (2001). Teamwork Quality and the Success of Innovative Projects: A Theoretical Concept and Empirical Evidence. Organization Science, 12(4), 435-449.

Huang, X., Soutar, G. N., \& Brown, A. (2004). Measuring new product success: an empirical investigation of Australian SMEs. Industrial Marketing Management, 33(2), 117-123.

Hult, G. T. M., \& Ketchen Jr., D. J. (2001). Does Market Orientation Matter?: A Test of the Relationship between Positional Advantage and Performance. Strategic Management Journal, 22(9), 899-906.

Hurley, R. F., \& Hult, G. T. M. (1998). Innovation, Market Orientation, and Organizational Learning: An Integration and Empirical Examination. Journal of Marketing, 62(3), 42-54.

Joinson, A. N. (2001). Self-disclosure in computer-mediated communication: The role of self-awareness and visual anonymity. European Journal of Social Psychology, 31(2), 177-192.

Kahn, K. B. (2001). Market orientation, interdepartmental integration and product development performance. Journal of Product Innovation Management, 18(5), 314-323.

Kaiser, H. F., \& Rice, J. (1974). Little Jiffy Mark. Educational and Psychological Measurement, 34, 111-117.

Kazanjian, R. K. (1988). Relation of Dominant Problems to Stages of Growth in Technology-Based New Ventures. The Academy of Management Journal, 31(2), 257-279

Keller, R. T. (2001). Cross-Functional Project Groups in Research and New Product Development: Diversity, Communications, Job Stress, and Outcomes. The Academy of Management Journal, 44(3), 547-555.

Kohli, A. K., \& Jaworski, B. J. (1990). Market Orientation: The Construct, Research Propositions, and Managerial Implications. The Journal of Marketing, 54(2), 1-18.

Li, H., \& Atuahene-Gima, K. (2001). Product Innovation Strategy and the Performance of New Technology Ventures in China. The Academy of Management Journal, 44(6), 1123-1134.

Luo, X., Rindfleisch, A., \& Tse, D. K. (2007). Working with Rivals: The Impact of Competitor Alliances on Financial Performance. JMR, Journal of Marketing Research, 44(1), 73-83.

Massey, G. R., \& Kyriazis, E. (2007). Interpersonal trust between marketing and R\&D during new product development projects. European Journal of Marketing, 41(9/10), 1146-1172.

Matsuno, K., Mentzer, J. T., \& Özsomer, A. (2002). The Effects of Entrepreneurial Proclivity and Market Orientation on Business Performance. The Journal of Marketing, 66(3), 18-32.

Mattson, B. E. (1985). Spotting a market gap for a new product. Long Range Planning, 18(1), 87-93.

Nakata, C., Im, S., Park, H., \& Ha, Y.-W. (2006). Antecedents and consequence of Korean and Japanese new product advantage. Journal of Business Research, 59(1), 28-36.

Nambisan, S. (2002). Designing Virtual Customer Environments for New Product Development: Toward a Theory. The Academy of Management Review, 27(3), 392-413.

Narver, J. C., \& Slater, S. F. (1990). The Effect of a Market Orientation on Business Profitability. Journal of Marketing, 54(4), 20-35. 
Narver, J. C., Slater, S. F., \& MacLachlan, D. L. (2004). Responsive and Proactive Market Orientation and New-Product Success. Journal of Product Innovation Management, 21(5), 334-347.

Noble, C. H., Sinha, R. K., \& Kumar, A. (2002). Market Orientation and Alternative Strategic Orientations: A Longitudinal Assessment of Performance Implications. Journal of Marketing, 66(4), 25-39.

Olson, E. M., Walker, O. C., \& Ruekert, R. W. (1995). Organizing for Effective New Product Development: The Moderating Role of Product Innovativeness. Journal of Marketing, 59(1), 48-62.

Olson, E. M., Walker, O. C., Ruekert, R. W., \& Bonner, J. M. (2001). Patterns of cooperation during new product development among marketing, operations and R\&D: Implications for project performance. Journal of Product Innovation Management, 18(4), 258-271.

Paladino, A. (2007). Investigating the Drivers of Innovation and New Product Success: A Comparison of Strategic Orientations. Journal of Product Innovation Management, 24(6), 534-553.

Pelham, A. M. (1999). Influence of Environment, Strategy, and Market Orientation on Performance in Small Manufacturing Firms. Journal of Business Research, 45(1), 33-46.

Ranchhod, A., \& Zhou, F. (2001). Comparing respondents of e-mail and mail surveys: understanding the implications of technology. Marketing Intelligence \& Planning, 19(4), 254-262.

Reagans, R., \& McEvily, B. (2003). Network Structure and Knowledge Transfer: The Effects of Cohesion and Range. Administrative Science Quarterly, 48(2), 240-267.

Rodríguez, N. G., Pérez, M. J. S., \& Gutiérrez, J. A. T. (2007). Interfunctional trust as a determining factor of a new product performance. European Journal of Marketing, 41(5/6), 678-702.

Rodríguez, N. G., Pérez, M. J. S., \& Gutiérrez, J. A. T. (2007a). Interfunctional climate and a new product performance: dependence as a moderator. European Journal of Marketing, 22(7), 459-473.

Rodríguez, N. G., Pérez, M. J. S., \& Gutiérrez, J. A. T. (2008). Can a good organizational climate compensate for a lack of top management commitment to new product development? Journal of Business Research, 61(2), 118-131.

Rust, R. T., Inman, J. J., Jia, J., \& Zahorik, A. (1999). What You Don't Know about Customer-Perceived Quality: The Role of Customer Expectation Distributions. Marketing Science, 18(1), 77-92.

Sethi, R., Smith, D. C., \& Park, C. W. (2001). Cross-Functional Product Development Teams, Creativity, and the Innovativeness of New Consumer Products. Journal of Marketing Research, 38(1), 73-85.

Shaw, C. T., Shaw, V., \& Enke, M. (2004). Relationships between engineers and marketers within new product development: An Anglo-German comparison. European Journal of Marketing, 38(5/6), 694-719.

Sherman, J. D., Berkowitz, D., \& Souder, W. E. (2005). New Product Development Performance and the Interaction of Cross-Functional Integration and Knowledge Management. Journal of Product Innovation Management, 22(5), 399-411.

Shin, H., Collier, D. A., \& Wilson, D. D. (2000). Supply management orientation and supplier/buyer performance. Journal of Operations Management, 18(3), 317-333.

Sivadas, E., \& Dwyer, F. R. (2000). An Examination of Organizational Factors Influencing New Product Success in Internal and Alliance-Based Processes. Journal of Marketing, 64(1), 31-49.

Song, M., \& Montoya-Weiss, M. M. (2001). The Effect of Perceived Technological Uncertainty on Japanese New Product Development. The Academy of Management Journal, 44(1), 61-80.

Song, M., Dyer, B., \& Thieme, R. (2006). Conflict management and innovation performance: An integrated contingency perspective. Journal of the Academy of Marketing Science, 34(3), 341-356.

Song, X. M., \& Parry, M. E. (1997). The Determinants of Japanese New Product Successes. Journal of Marketing Research, 34(1), 64-76.

Song, X. M., Neeley, S. M., \& Zhao, Y. (1996). Managing R\&D-Marketing Integration in the New Product Development Process, Industrial Marketing Management, 25, 545-553.

Song, X. M., Xie, J., \& Dyer, B. (2000). Antecedents and Consequences of Marketing Managers' Conflict-Handling Behaviors. Journal of Marketing, 64(1), 50-66.

Sriram, V., \& Stump, R. (2004). Information technology investments in purchasing: an empirical investigation of communications, relationship and performance outcomes. Omega, 32(1), 41-55.

Stevens, G. A. \& Burley, J. (2003). Piloting the rocket of radical innovation. Research Technology Management, 46(2), 16-26

Suler, J. (2004). The Online Disinhibition Effect. CyberPsychology and Behavior, 7(3), 321-326.

Swink, M., \& Song, M. (2007). Effects of marketing-manufacturing integration on new product development time and competitive advantage. Journal of Operations Management, 25(1),.203-217. 
Tse, A. C. B., Sin, L. Y. M., Yau, O. H. M., Lee, J. S. Y., \& Chow, R. (2004). A firm's role in the marketplace and the relative importance of market orientation and relationship marketing orientation. European Journal of Marketing, 38(9/10), 1158-1172.

Voss, G. B., \& Voss, Z. G. (2000). Strategic Orientation and Firm Performance in an Artistic Environment. Journal of Marketing, 64(1), 67-83.

Wilson, I. (1992). Realizing the power of strategic vision. Long Range Planning, 25(5), 18-28.

Zirger, B. J., \& Maidique, M. A. (1990). A Model of New Product Development: An Empirical Test. Management Science, 36(7), 867-883.

Table 1. Exploratory Factor Loadings of Measurement Scales

\begin{tabular}{|l|c|c|c|c|}
\hline \multirow{2}{*}{ Measuring Scales } & \multicolumn{3}{|c|}{ Latent Variables } & \\
\cline { 2 - 5 } & $\begin{array}{c}\text { R\&D-Marketing } \\
\text { Cooperation }\end{array}$ & $\begin{array}{c}\text { New Product } \\
\text { Success }\end{array}$ & & \\
\hline Coop1 & 0.666 & & & \\
Coop2 & 0.684 & & & \\
Coop3 & 0.696 & & & \\
Coop4 & 0.655 & & & \\
Coop5 & 0.654 & 0.738 & & \\
Coop6 & 0.687 & 0.791 & & \\
NPS1 & & 0.816 & 0.749 & \\
NPS2 & & & 0.774 & \\
NPS3 & & & 0.787 & \\
Cust1 & & & 0.759 & \\
Cust2 & & & 0.784 & \\
Cust3 & & & & \\
Cust4 & & & & \\
Cust5 & & & \\
Comp1 & & & \\
Comp2 & & & & \\
Comp3 & & & & \\
Comp4 & & & & \\
\hline Remark: $\mathrm{n}=207$ & & & & \\
\hline
\end{tabular}

Table 2. Cronbach's Alpha coefficients of Latent Variables

\begin{tabular}{|l|c|c|}
\hline Latent Variable & Cronbach's Alpha & Number of items \\
\hline R\&D-Marketing Cooperation & 0.819 & 6 \\
New Product Success & 0.854 & 3 \\
Customer Orientation & 0.918 & 5 \\
Competitor Orientation & 0.857 & 4 \\
\hline
\end{tabular}

Table 3. Correlations of Latent Variables

\begin{tabular}{|l|c|c|c|}
\hline \multicolumn{1}{|c|}{ Latent Variable } & $\begin{array}{c}\text { New Product } \\
\text { Success }\end{array}$ & $\begin{array}{c}\text { Customer } \\
\text { Orientation }\end{array}$ & $\begin{array}{c}\text { Competitor } \\
\text { Orientation }\end{array}$ \\
\hline R\&D-Marketing Cooperation & 0.595 & 0.568 & 0.306 \\
New Product Success & & 0.585 & 0.291 \\
Customer Orientation & & & 0.541 \\
\hline
\end{tabular}

Note: All correlations are significant at 0.01 level. 
Table 4. Mediating Effect of Customer Orientation

\begin{tabular}{|l|c|c|c|c|}
\hline Equation & 1 & 2 & 3 & 4 \\
\hline Dependent Variable & $\begin{array}{c}\text { New Product } \\
\text { Success }\end{array}$ & $\begin{array}{c}\text { Customer } \\
\text { Orientation }\end{array}$ & $\begin{array}{c}\text { New Product } \\
\text { Success }\end{array}$ & $\begin{array}{c}\text { New Product } \\
\text { Success }\end{array}$ \\
\hline $\begin{array}{l}\text { Independent Variable(s): } \\
\text { R\&D-Marketing Cooperation }\end{array}$ & 0.595 & 0.568 & - & 0.388 \\
Customer Orientation & & & 0.585 & 0.365 \\
\hline
\end{tabular}

Note: All correlations are significant at 0.01 level.

Table 5. Mediating Effect of Competitor Orientation

\begin{tabular}{|l|c|c|c|c|}
\hline Equation & 1 & 2 & 3 & 4 \\
\hline Dependent Variable & $\begin{array}{c}\text { New Product } \\
\text { Success }\end{array}$ & $\begin{array}{c}\text { Competitor } \\
\text { Orientation }\end{array}$ & $\begin{array}{c}\text { New Product } \\
\text { Success }\end{array}$ & $\begin{array}{c}\text { New Product } \\
\text { Success }\end{array}$ \\
\hline $\begin{array}{l}\text { Independent Variable(s) } \\
\text { R\&D-Marketing Cooperation } \\
\text { Competitor Orientation }\end{array}$ & 0.595 & 0.306 & - & 0.558 \\
\hline
\end{tabular}

Note: All correlations are significant at 0.01 level; except $*$ at $\mathrm{p}<0.05$

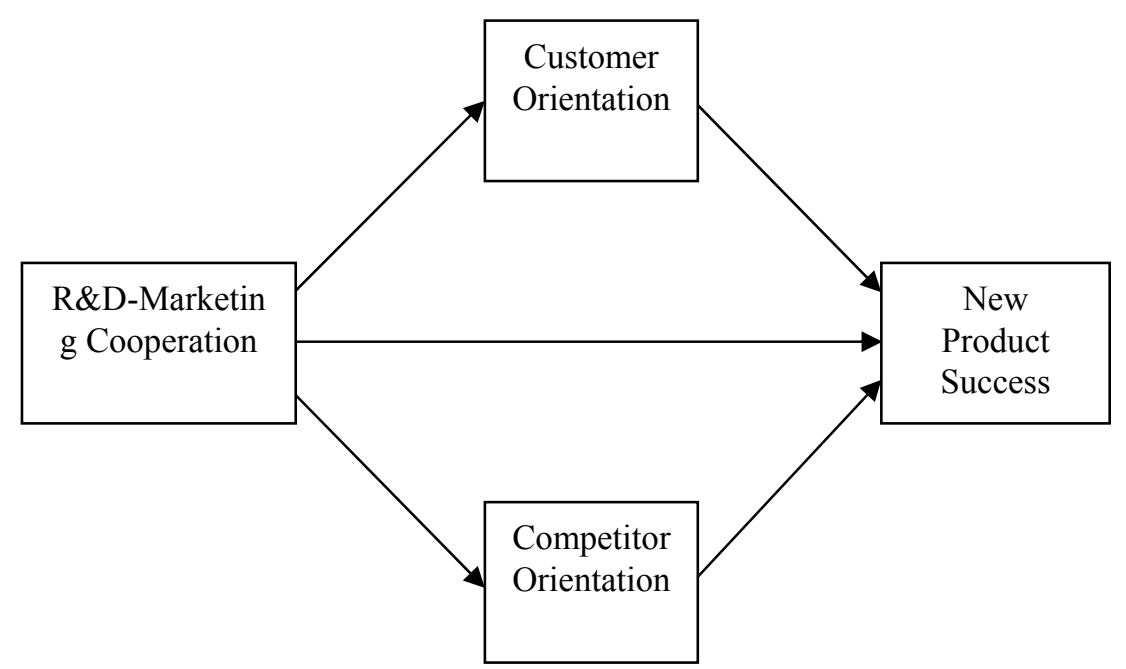

Figure 1. Proposed Research Model 